\title{
Diaphragmatic eventration presenting with sudden dyspnoea
}

\author{
Mehmet Deveer, ${ }^{1}$ Halil Beydilli, ${ }^{2}$ Nesat Cullu, ${ }^{1}$ Ali Kemal Sivrioglu ${ }^{3}$
}

${ }^{1}$ Department of Radiology, School of Medicine, Mugla Sitki Kocman University, Mugla, Turkey

${ }^{2}$ Department of Emergency Medicine, School of Medicine, Mugla Sitki Kocman University, Mugla, Turkey

Department of Radiology, Aksaz Military Hospital, Mugla, Turkey

Correspondence to Dr Mehmet Deveer, deveer3@hotmail.com
To cite: Deveer $\mathrm{M}$, Beydilli $H$, Cullu N, et al. BMJ Case Rep Published online: [please include Day Month Year] doi:10.1136/ bcr-2013-008613

\section{DESCRIPTION}

Eventration of the diaphragm is an abnormal elevation of an intact diaphragm. There are two distinct aetiological types of eventration: congenital and acquired. The acquired diaphragmatic eventration is rarely seen in adults and the most common aetiological type for acquired disease is cardiac surgery. ${ }^{1}$ It may be asymptomatic or cause recurrent infections by changing pulmonary inflation. Eventration of the diaphragm should be considered as a risk factor for tension pneumothorax. ${ }^{2}$ Unilateral diaphragm eventration is a frequent event in which more than half of the cases are diagnosed incidentally. Dyspnoea during exercises is the most common symptom. The vital capacity is reduced by approximately $25 \%$ and the total lung capacity by approximately $15 \%$ by the unilateral diaphragmatic paralysis. ${ }^{3}$ We present a case of a diaphragmatic eventration in an adult patient.

A 64-year-old man was referred to our emergency unit with a sudden onset of severe dyspnoea after a strong cough. His medical and family histories were unremarkable. Thorax CT revealed left diaphragmatic elevation, dilated segment of colon and replacement of spleen and stomach to the subdiaphragmatic area (figures 1-3). Pneumonic infiltration was also seen. We consider that acute dyspnoea developed because of restriction caused by eventration and existing pulmonary inflammation. Diagnostic laparoscopy was performed and the diagnosis of diaphragmatic eventration was made.

Diaphragmatic pathologies must be considered in patients referring to emergency services with a sudden onset of dyspnoea. CT is important for the diagnosis.

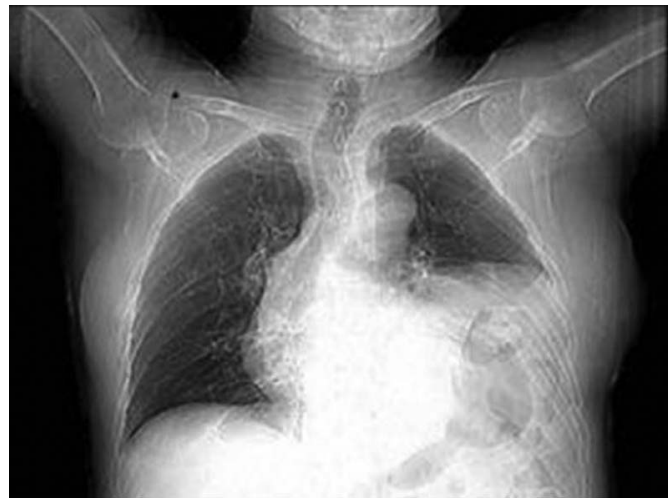

Figure 1 CT scanogram image showing a raised left hemidiaphragm.

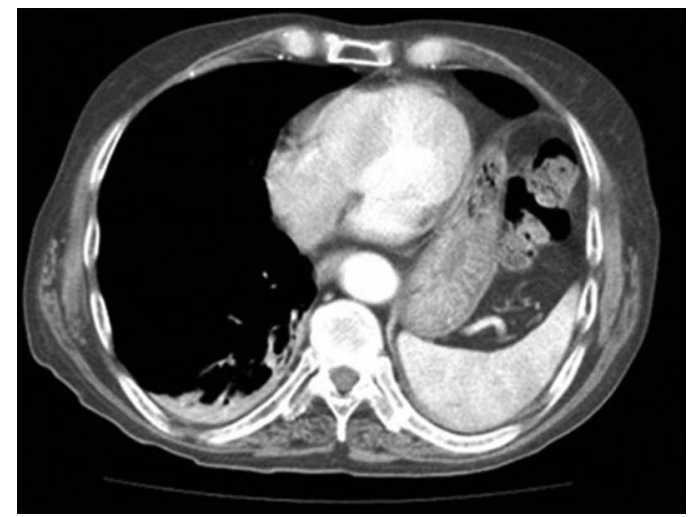

Figure 2 Axial CT image showing the stomach and intestinal loops displaced into the left thoracic cavity.

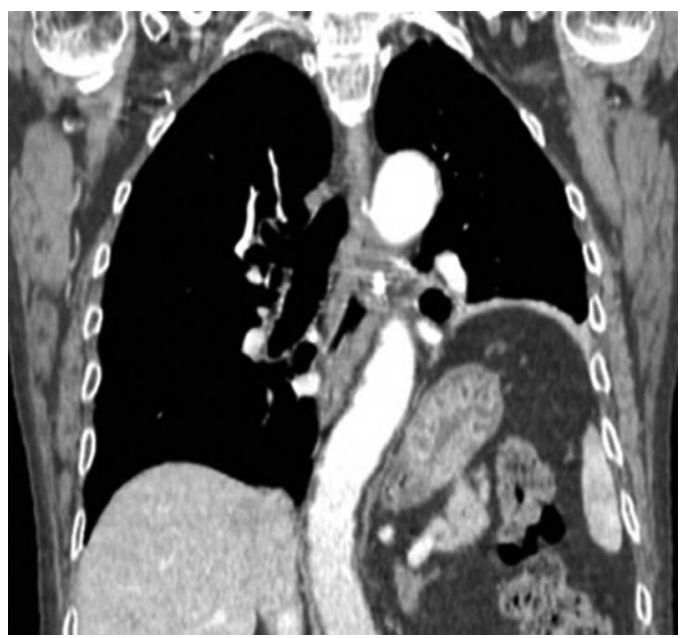

Figure 3 Reformatted CT image confirms diaphragmatic eventration.

\section{Learning point}

Diaphragmatic pathologies must be considered in patients referring to emergency services with a sudden onset of dyspnoea. CT is important for the diagnosis.

Competing interests None.

Patient consent Obtained.

Provenance and peer review Not commissioned; externally peer reviewed. 


\section{REFERENCES}

1 Large SR, Heywood LJ, Flower CD, et al. Incidence and aetiology of a raised hemidiaphragm after cardiopulmonary bypass. Thorax 1985;40:444-7.
2 Akoglu H, Coban E, Guneysel O. Tension pneumoperitoneum complicated with tension pneumothorax in a patient with diaphragmatic eventration. BMJ Case Rep 2012;10.1136/bcr.01.2012.5512, 4 April 2012

3 Murray JF, Nadel JA. Textbook of respiratory medicine. 3rd edn. London: WB Saunders2000:2329-56.

Copyright 2013 BMJ Publishing Group. All rights reserved. For permission to reuse any of this content visit http://group.bmj.com/group/rights-licensing/permissions.

BMJ Case Report Fellows may re-use this article for personal use and teaching without any further permission.

Become a Fellow of BMJ Case Reports today and you can:

- Submit as many cases as you like

- Enjoy fast sympathetic peer review and rapid publication of accepted articles

- Access all the published articles

- Re-use any of the published material for personal use and teaching without further permission

For information on Institutional Fellowships contact consortiasales@bmjgroup.com

Visit casereports.bmj.com for more articles like this and to become a Fellow 